\title{
Correction to: The UN Global Compact for Transnational Business and Peace: A Need for Orchestration?
}

\author{
Mariko Shoji
}

\section{Correction to:}

Chapter "The UN Global Compact for Transnational Business and Peace: A Need for Orchestration?" in: M. M. Rahim (ed.), Code of Conduct on Transnational Corporations, CSR, Sustainability, Ethics \& Governance, https://doi.org/10.1007/978-3-030-10816-8_5

The original version of the book was inadvertently published with incorrect information in chapter "The UN Global Compact for Transnational Business and Peace: A Need for Orchestration?"; the corrections are given below.

Page 92, Table 1, the text 'PRI(Delet)' in Case 3 has been deleted.

Page 94, Table 3, the word 'Contribution' has been added after 'Profit Led'. The chapter has now been corrected. 